\title{
Physiochemical Analysis of Groundwater at Kataeregi Mining Site, Niger State, North Central Nigeria
}

\author{
Jamilu Shehu ${ }^{1,}$, , Usman Defyan Alhassan ${ }^{1}$, Abdulwaheed Adewuyi Rafiu ${ }^{1}$, Abdullahi Idris-Nda ${ }^{2}$ \\ ${ }^{1}$ Department of Geophysics, Federal University of Technology, Minna, Nigeria \\ ${ }^{2}$ Department of Geology, Federal University of Technology, Minna, Nigeria
}

Email address:

jameelshehu@futminna.edu.ng (J. Shehu)

${ }^{*}$ Corresponding author

\section{To cite this article:}

Jamilu Shehu, Usman Defyan Alhassan, Abdulwaheed Adewuyi Rafiu, Abdullahi Idris-Nda. Physiochemical Analysis of Groundwater at Kataeregi Mining Site, Niger State, North Central Nigeria. International Journal of Environmental Monitoring and Analysis.

Vol. 9, No. 5, 2021, pp. 109-113. doi: 10.11648/j.ijema.20210905.11

Received: August 14, 2021; Accepted: August 25, 2021; Published: September 3, 2021

\begin{abstract}
Groundwater samples were analysed to determine the heavy metals (pH, $\mathrm{Cd}, \mathrm{Zn}, \mathrm{Cu}, \mathrm{Cr}, \mathrm{Pb}, \mathrm{Hg}, \mathrm{Ar}, \mathrm{Fe}$ and $\mathrm{Ni}$ ) at Kataeregi mining site, Niger State, Nigeria. Ten groundwater samples were collected. Four samples of groundwater were collected from control site $100 \mathrm{~m}$ away from mining site. The results of the analysed water samples are as follows: The concentration level of Cadmium ranges from $0.000 \mathrm{mg} / \mathrm{L}$ to $0.003 \mathrm{mg} / \mathrm{L}$ while the control site is $0.000 \mathrm{mg} / \mathrm{L}$, Copper ranges between $0.000 \mathrm{mg} / \mathrm{L}$ and $0.515 \mathrm{mg} / \mathrm{L}$ and that of the control site is $0.055 \mathrm{mg} / \mathrm{L}$, Zinc ranges from $0.000 \mathrm{mg} / \mathrm{L}$ to $0.111 \mathrm{mg} / \mathrm{L}$ with its control site of $0.095 \mathrm{mg} / \mathrm{L}$, all three analysed samples falls far below the permissible limit. Iron concentration varies from $0.03 \mathrm{mg} / \mathrm{L}$ and $13.6 \mathrm{mg} / \mathrm{L}$ with control site of $0.15 \mathrm{mg} / \mathrm{L}$, all are above tolerable limit, arsenic ranges from $0.002 \mathrm{mg} / \mathrm{L}$ to $0.026 \mathrm{mg} / \mathrm{Land}$ the control site is $0.00 \mathrm{mg} / \mathrm{L}$. Nitrate concentration level found is far above the WHO and NSDWQ standard with the values ranging from $16.50 \mathrm{mg} / \mathrm{L}$ to $323.7 \mathrm{mg} / \mathrm{L}$ with the control well value stands at $29.0 \mathrm{mg} / \mathrm{L}$, well ${ }_{1}$, well ${ }_{3}$ and well ${ }_{4}$ values are all above tolerable limit. Mercury has concentration level ranging from $0.000 \mathrm{mg} / \mathrm{L}$ to $0.022 \mathrm{mg} / \mathrm{L}$ with well ${ }_{2}$ been the possible contaminant, the control site remains at $0.000 \mathrm{mg} / \mathrm{L}$ while chromium has values ranging from $0.000 \mathrm{mg} / \mathrm{L}$ to 0.080 $\mathrm{mg} / \mathrm{L}$ with well ${ }_{1}$ having the value above the NSDWQ standard with control site value of $0.00 \mathrm{mg} / \mathrm{L}$ and lead concentration value ranging between $0.000 \mathrm{mg} / \mathrm{L}$ and $0.001 \mathrm{mg} / \mathrm{L}$ having control well value of $0.000 \mathrm{mg} / \mathrm{L}$.
\end{abstract}

Keywords: Groundwater, Concentration, Mercury, Control Site, Sample

\section{Introduction}

The sustainable management of waste approach aimed at global environmental quality, and environmental quality is a prerequisite for a rise in per capital welfare over a period of time. Efficient management of waste is a global concern requiring extensive research and developmental work towards exploring newer application for a sustainable and environmentally sound management. The problem of waste management is a primordial one and presents issues in developing countries in Africa, particularly Nigeria [5].

Water and sanitation are among the basic requirements for life [8]. According to United Nations Sustainable Development goals on water and sanitation, about 2 billion people in the world are living in areas classified as water stress. The availability of water resources in quality and quantity is a prerequisite in dealing with the sustainability of the resources. Rapid population increase across the globe has resulted in an increase in food production, thereby putting a lot of stress on water resources [7]. In recent times people have resorted to groundwater for their potable use, especially in developing countries [9]. Observations have shown that the reliance on groundwater resources has risen because of quality issues associated with the use of surface water. The quality of groundwater, however, varies spatially in response to geogenic and anthropogenic factors [3] which warrants an assessment of the water quality to serve the purpose for which it is used.

The earth subsurface has become the safest and most abundant source of potable water in comparison to the earth's surface as it is often shielded from direct human activities. 
However, any undetected contamination of this resource poses a threat to the well-being and continuous existence of man in the environment. Contamination is the pollution involving constituents that are hazardous to health because of their nature or quality [1]. Groundwater is transmitted through a deep aquifer comprising unconsolidated weathered materials that form the overlying mantle or regolith [10].

Mining generates a large quantum of tailing otherwise termed as slimes or leach residue, basically a mixture of fine disintegrated mineral particles and fluid, which needs to be disposed safely without causing any environmental hazard like leaching and erosion by wind or water. The global legacy of mining and disposal of tailings had been for more than few centuries. Tailings facilities consist of tailings pond or lagoons, tailings dam and tailings transport systems (generally pipelines). Usually a very large area is required to contain the tailings which is man-made, and is the most critical element of these facilities. The surface disposal site is to be characterised for its sub-surface nature in order to understand its role in mapping the subsurface geological formation in terms of it geophysical parameters in and around the waste disposal site [12]. A mining site is usually a complex industrial system handling huge amounts of rocks in order to extract from them a lower or marginal amount of valuable metals or minerals. It comprises thus two activities: extraction and ore processing. The sheer mass of the handled material implies that the valuable commodity is extracted or concentrated near site, and most of the waste is disposed of nearby. The specificity of mine waste required adapted regulations and standards [2].

\subsection{Description of the Study Area}

The study area (Kataeregi) is located $39 \mathrm{~km}$ along Minna Bida road, in Katcha Local Government Area of Niger State, North-central Nigeria (Figure 1). The area is part of Bida Sheet $184 \mathrm{NE}$ and is located between Latitudes $09^{\circ} 21^{\prime} \mathrm{N}$ and $09^{\circ} 25^{\prime} \mathrm{N}$ and Longitudes $006^{\circ} 17^{\prime} \mathrm{E}$ and $006^{\circ} 22^{\prime} \mathrm{E}$ on the scale of $1: 25,000$ covering a total area of about $68 \mathrm{~km}^{2}$ [11]. It lies between the geographical co-ordinates of Northing's $811400-813200 \mathrm{mN}$ and Easting's $732200-733400 \mathrm{mE}$ in the Universal Traverse Mercator (UTM) Minna Zone 31 [4]. The topographic elevation around the site ranges from 335.0 to $365.0 \mathrm{~m}$ above mean sea level and generally slopes gently from the north towards the southern part. The area has a climate characterized by two seasons; the wet season and the dry season. The wet season starts from around mid-April and ends in October with an average rainfall of $1500 \mathrm{~mm}$ to $2000 \mathrm{~mm}$ while the dry season starts around November and ends in March with an average maximum temperature of about $33^{\circ} \mathrm{C}$ [4].

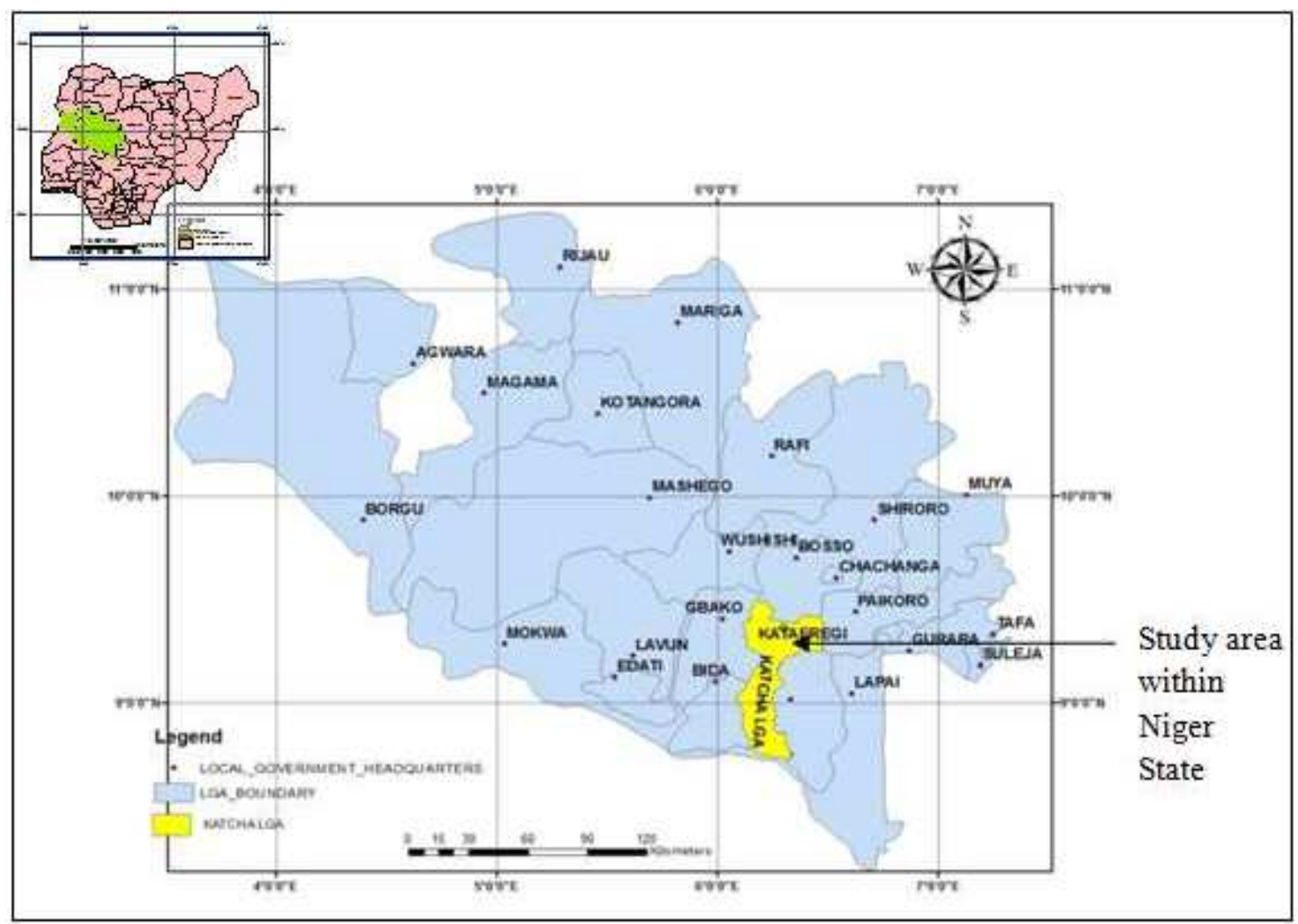

Figure 1. Location map of Kataeregi, Niger State, Nigeria [11].

\subsection{Geology of the Study Area}

The area consists of mixed geology of both basement and sedimentary rocks. The rocks units consist of schists, migmatites, gneisses, granites, quartzite of Precambrian age ( $>550$ million years old) [6]. The area is dominated by 
schistose rocks that serves as host to auriferous quartz vein where the mining is taking place. The schists are intercalated with amphibolites observable along the River Chanchaga, the schists had already been mapped and considered as part of the Kusharki Schists. The schists are intruded by plutonic rock and exposed at sabon Eregi and Kataeregi with xenoliths of phyllites. The study area is dominated by migmatites-gneisses complex and granites at the North and South-eastern parts and Bida sandstone to the extreme Southwestern part [11]. The sedimentary terrain falls within the Bida Basin of central Nigeria and covers the central and southern part of the state. The rocks of the basin comprise of conglomerates, sandstones, siltstones, mudstones and ironstones [6].

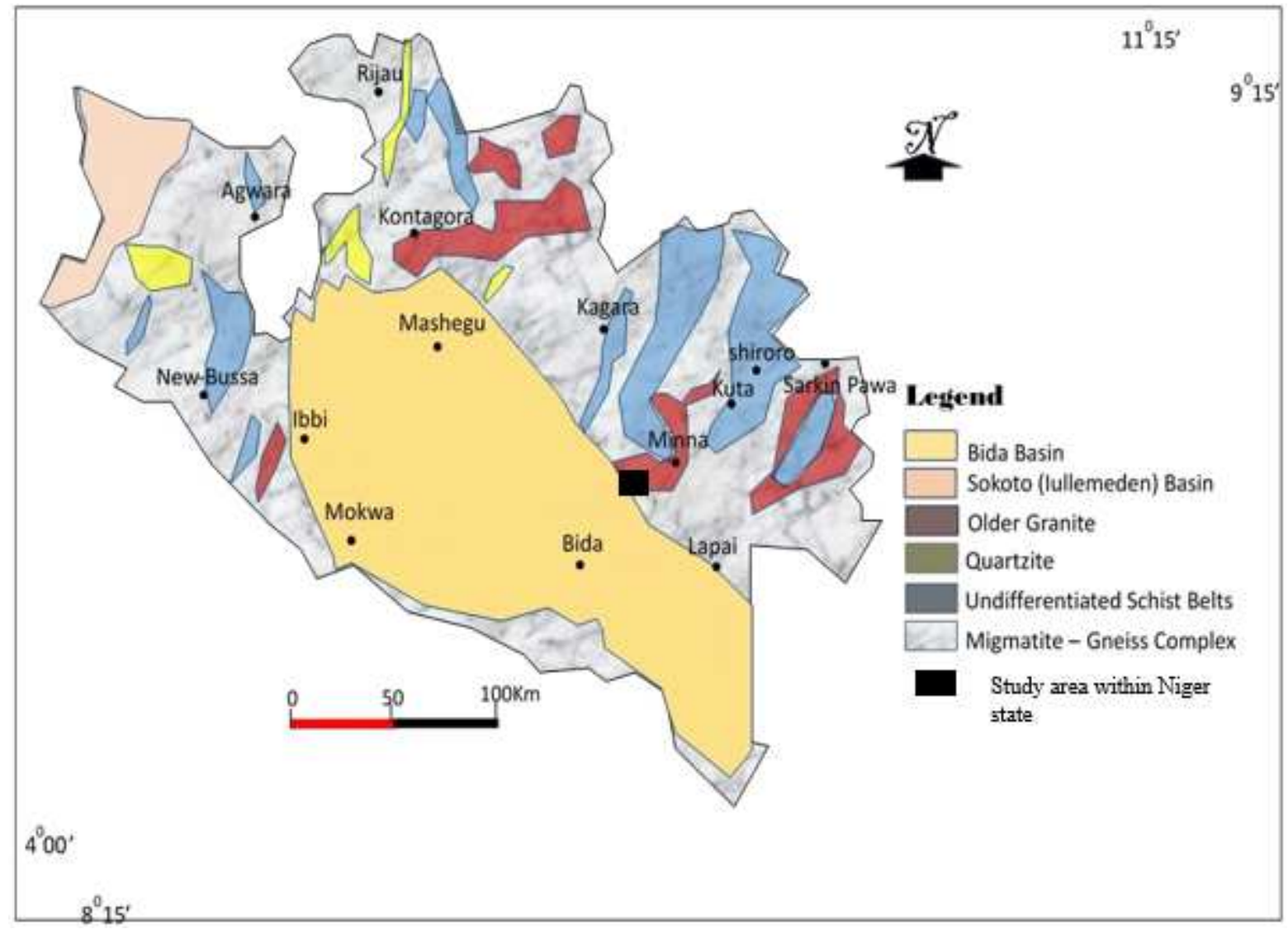

Figure 2. Geological Map of the Study Area [6].

\section{Methodology}

Five water samples were collected from the untreated well and mine pits around the mining site, the groundwater samples from the fetched bucket which was cleansed with distilled water was then transferred into plastic bottles which was capped and clearly labelled. The water temperature, electrical conductivity, and $\mathrm{pH}$ of all the water samples were measured and recorded on the field. The concentration of lead, zinc, nitrate, arsenic, iron, copper chromium, mercury and cadmium were determined.

Hydrochemical Analysis

In order to carry out pollution assessment of the study area, hydrochemical analysis of water samples were collected from five wells/pits around the mining site. The sampling wells were designated $\mathrm{W}_{1}$ to $\mathrm{W}_{5}$ which stand for well ${ }_{1}$ to well 5 . The physiochemical parameters that are indicative of groundwater pollution such as copper, cadmium, zinc, chromium, lead, iron, mercury, nitrate and arsenic were analysed. All samples were analysed using standard methods recommended by the American Public Health Association (APHA 19 $9^{\text {th }}$ edition, 1995). Results were compared with Nigerian Standard for Drinking Water Quality (NSDWQ, 2015). HM 5000 Metelyser and Colorimeter was used to ascertain the concentration of heavy metals in groundwater at the Federal Ministry of Water Resources, Regional Water Quality Laboratory, Minna, Nigeria.

\section{Results and Discussion}

Physical parameters

Table 1 shows the values of physiochemical parameters determined, the World Health Organisation and Nigerian Standard for Drinking Water Quality standard with their health impact. The temperature ranges from 30.9 to $31.9^{\circ} \mathrm{C}$ which is lower than the World Health Organisation (WHO) limit. Lower temperature may indicate the presence of pollutants [11].

The $\mathrm{pH}$ values ranges from 6.70 to 7.04 which is below the limit and within the allowable consumption limit. Total 
Dissolve Solids varies from 210 to $338 \mathrm{mg} / \mathrm{L}$ which is normal and fall below the standard and thereby recommended for domestic purposes. Electrical Conductivity varies from 323 to $520 \mu \mathrm{Scm}^{-1}$, this is also within the prescribed values by World Health Organisation (WHO) and Nigerian Standard for Drinking Water Quality (NSDWQ).

Table 2 shows maximum and minimum concentration of determined parameters and percentage compliance for the sampled parameters. The concentration level of Cadmium ranges from $0.000 \mathrm{mg} / \mathrm{L}$ and $0.003 \mathrm{mg} / \mathrm{L}$ while the control site is $0.000 \mathrm{mg} / \mathrm{L}$, Copper ranges between $0.000 \mathrm{mg} / \mathrm{L}$ and $0.515 \mathrm{mg} / \mathrm{L}$ likewise the control site is $0.055 \mathrm{mg} / \mathrm{L}$, Zinc ranges from $0.000 \mathrm{mg} / \mathrm{L}$ and $0.111 \mathrm{mg} / \mathrm{L}$ control site is 0.095 $\mathrm{mg} / \mathrm{L}$, all three analysed samples fall far below the permissible limit, and the percentage compliance level is $100 \%$. Iron concentration varies from $0.03 \mathrm{mg} / \mathrm{L}$ and 13.6 $\mathrm{mg} / \mathrm{L}$ with control site is $0.15 \mathrm{mg} / \mathrm{L}$ as shown in table 1 with is $\mathrm{W}_{1}, \mathrm{~W}_{2}$, all above tolerable limit and the percentage compliance is $50 \%$, arsenic ranges from $0.002 \mathrm{mg} / \mathrm{L}$ and $0.026 \mathrm{mg} / \mathrm{L}$ with well ${ }_{1}$ and ${ }_{4}$ been the affected, the control site at $0.00 \mathrm{mg} / \mathrm{L}$ and the percentage compliance is $50 \%$, nitrate concentration level fall far above the WHO and NSDWQ standard with the values ranging from $323.7 \mathrm{mg} / \mathrm{L}$ and $16.50 \mathrm{mg} / \mathrm{L}$ with control well stands at $29.0 \mathrm{mg} / \mathrm{L}$, with well ${ }_{1}, 3$ and ${ }_{4}$ all above tolerable limit and the percentage compliance is $25 \%$. Mercury has concentration level ranging from $0.000 \mathrm{mg} / \mathrm{L}$ and $0.022 \mathrm{mg} / \mathrm{L}$ with well 2 been the possible contaminant, the control site remain at $0.000 \mathrm{mg} / \mathrm{L}$ and the percentage compliance is $75 \%$ while chromium has values ranging from $0.000 \mathrm{mg} / \mathrm{L}$ and $0.080 \mathrm{mg} / \mathrm{L}$ with well ${ }_{1}$ having the value above the standard and the percentage compliance is $75 \%$ with control site $0.00 \mathrm{mg} / \mathrm{L}$ and lead concentration value ranging between $0.000 \mathrm{mg} / \mathrm{L}$ and 0.001 $\mathrm{mg} / \mathrm{L}$ with control well at $0.000 \mathrm{mg} / \mathrm{L}$ and the percentage compliance is $100 \%$.

Table 1. Summary of Physiochemical parameters of Water Samples and Standards.

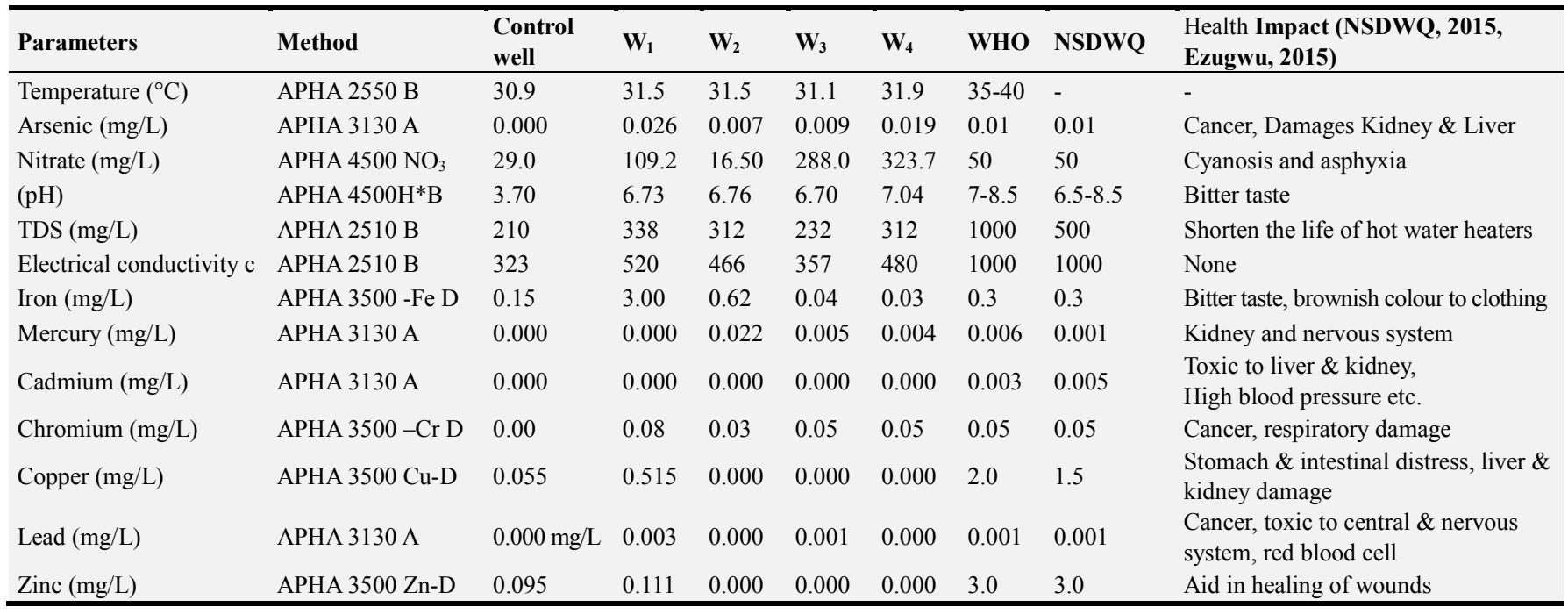

Table 2. Comparison of Physiochemical parameters of Water Samples with percentage compliance to WHO 2004 \& NSDWQ, 2015).

\begin{tabular}{|c|c|c|c|c|c|}
\hline Parameters & Minimum & Maximum & Percentage compliance (\%) & WHO & NSDWQ \\
\hline Temperature $\left({ }^{\circ} \mathrm{C}\right)$ & 30.9 & 31.9 & 100 & $35-40$ & - \\
\hline Arsenic (mg/L) & 0.002 & 0.026 & 50 & 0.01 & 0.01 \\
\hline Nitrate (mg/L) & 16.50 & 323.7 & 25 & 50 & 50 \\
\hline$(\mathrm{pH})$ & 6.70 & 7.04 & 100 & $7-8.5$ & $6.5-8.5$ \\
\hline TDS (mg/L) & 210 & 338 & 100 & 1000 & 500 \\
\hline Electrical conductivity $\mu \mathrm{Scm}^{-1}$ & 323 & 520 & 100 & 1000 & 1000 \\
\hline Iron $(\mathrm{mg} / \mathrm{L})$ & 13.6 & 0.03 & 50 & 0.3 & 0.3 \\
\hline Cadmium (mg/L) & 0.000 & 0.003 & 100 & 0.003 & 0.005 \\
\hline Chromium (mg/L) & 0.00 & 0.08 & 75 & 0.05 & 0.05 \\
\hline Copper (mg/L) & 0.000 & 0.515 & 100 & 2.0 & 1.5 \\
\hline Lead (mg/L) & 0.00 & 0.017 & 100 & 0.001 & 0.001 \\
\hline Zinc (mg/L) & 0.000 & 0.111 & 100 & 3.0 & 3.0 \\
\hline
\end{tabular}

\section{Conclusion}

The result of geochemical parameters on analysed groundwater are within the specified limit set by World Health Organisation, Nigerian Standard Drinking Water
Quality. However the activity of artisanal mining in the area has impacted on the environment with about $20 \%$ of the area directly or indirectly contaminated as shown in Tables 1 and 2 respectively. The possible contamination may be as a result of element migration and extent of migration depth.

Consequently the activities has led to environmental 
degradation and loss of vegetation, therefore regulations and remediation methods should be in place to checkmate the effect during and after the mining activities. The activity of artisanal gold mining in the area can generated large amount of waste leaving large heaps of excavated soils from trenches and tailings generated during processing creates an artificial barrier for surface run-off. This has led to the modification in the stream channels by disrupting the initial channel and creating new ones.

Omanayin et al stated that mining activities can cause a change in the natural geology of the area promoting geological hazards like erosion and flooding [11].

\section{Recommendation}

Electrical resistivity method (vertical electrical sounding) be employed to delineate the lateral and depth extent of contaminated leachate plume migration and to map out subsurface structures that could acts as pathway for flow of contaminant.

\section{References}

[1] Adelusi. A. O., Akinlalu A. A. and Adebayo S. S. (2013). Geophysical and Hydrochemistry Methods for Mapping Groundwater Contamination around Aule area, Akure, Southwestern Nigeria, International Journal of Water Resources and Environmental Engineering, 5 (7): 442-451.

[2] Alexandros Liakopoulos, Bruno Lemiere, Konstantinos Micheal, Catherine Crouzet, Valerie Laperche (2010). Environmental Impacts of Unmanaged Solid Waste at a Former Metal Mining and Ore Processing Site, Waste Management and Research, 28 (11), 996-1009.

[3] Annapoorna H. and Janardhana M. R. (2015). Assessment of Groundwater Quality for Drinking Purpose in Rural Areas Surrounding a Defunct Copper Mine. Aquatic Procedia, (4). 685-692.
[4] Bayode and Adeniyi, (2014). Integrated geophysical and hydrochemical investigation of pollution Associated with the Ilara-Mokin Dumpsite, Southwestern Nigeria. American International Journal of Contemporary Research, 4 (2): 150-160.

[5] Beatrice Abila and Jussi Kantola (2013). Municipal Solid Waste Management Problems in Nigeria: Evolving Knowledge Management Solution. International /Journal of Environmental and Ecological Engineering, 7 (6): 303-308.

[6] Idris-Nda A., Waziri N. M., Bida A. D. and Abdullahi S. (2018) Socio-Economic Impacts of Artisanal and Small-Scale Mining in Parts of Niger State, Central Nigeria. International Journal of Mining Science (IJMS), 4 (3): 21 - 30.

[7] Kalaivanan K., Gurugnanam, B., Hamid Reza Pourghasemi, Suresh, M. and Kumaravel S., (2017). Spatial assessment of groundwater quality using water quality index and hydrochemical indices in the Kodavanar sub-basin, Tamil Nadu, India. Sustain Water Resources Management. 15 pp.

[8] Mara, D. and Evans, B. (2011). Sanitation and water supply in low-income countries. Ventus Publishing, $142 \mathrm{pp}$.

[9] Massally, R-E. M., Sheriff, A. B., Kaitibi, D., Abu, A., Barrie, M. and Taylor, E. T. (2017). Comprehensive Assessment of Groundwater Quality around a Major Mining Company in Southern Sierra Leone. Journal of Water Resource and Protection. (9), 601-613.

[10] Morrisson BL, Lawrence ARL, Chilton PJC, Adams B, Calow RC, Klinck BA (2003). Groundwater and its susceptibility to degradation: A global assessment of the problem and options for management. Early Warning and Assessment Report Series, RS. 03-3. Nairobi, Kenya: United Nations Environment Programme, p. 126.

[11] Omanayin, Y. A., Ogunbajo, M. I., Waziri, N. M., Ako, T. A., Shuaibu, A. M and Alaku, I. O. (2016) Geochemical Investigation and Physical Impact Assessment of Artisanal Gold Mining, Kataeregi, North-Central Nigeria, International Journal of Science for Global Sustainability, 2 (2). 21-35.

[12] Rolland Andrade and Karunakar Goud B. (2011). Geophysical prospecting as a tool for site characterisation for mining dump waste, e-Journal Earth Science India. Popular Issue. www.earthscienceindia.info. 